\title{
Ginsenoside Rb1 as an Anti-Diabetic Agent and Its Underlying Mechanism Analysis
}

\author{
Ping Zhou ${ }^{1,2,3,4}$, Weijie Xie ${ }^{1,2,3,4}$ (D), Shuaibing He 1,2,3,4, Yifan Sun $^{5}$, Xiangbao Meng ${ }^{1,2,3,4}$, \\ Guibo Sun $1,2,3,4, *$ and Xiaobo Sun $1,2,3,4, *$
}

1 Institute of Medicinal Plant Development, Peking Union Medical College and Chinese Academy of Medical Sciences, Beijing 100193, China; zhoup0520@163.com (P.Z.); ginseng123@163.com (W.X.); wym91116@163.com (S.H.); xbmeng@implad.ac.cn (X.M.)

2 Beijing Key Laboratory of Innovative Drug Discovery of Traditional Chinese Medicine (Natural Medicine) and Translational Medicine, Institute of Medicinal Plant Development, Peking Union Medical College and Chinese Academy of Medical Sciences, Beijing 100193, China

3 Key Laboratory of Bioactive Substances and Resource Utilization of Chinese Herbal Medicine, Ministry of Education, Beijing 100193, China

4 Key Laboratory of Efficacy Evaluation of Chinese Medicine against Glycolipid Metabolic Disorders, State Administration of Traditional Chinese Medicine, Beijing 100193, China

5 Institute of Medical Information, Chinese Academy of Medical Sciences, Beijing 100020, China; sun.yifan@imicams.ac.cn

* Correspondence: sunguibopaper@163.com (G.S.); sunxiaobo@163.com (X.S.)

Received: 8 December 2018; Accepted: 23 February 2019; Published: 28 February 2019

\begin{abstract}
Panax ginseng and Panax notoginseng, two well-known medical plants with economic value, have a long history of use for managing various diseases in Asian countries. Accumulating clinical and experimental evidence suggests that notoginsenosides and ginsenosides, which are the major bioactive components of the plants, have a variety of beneficial effects on several types of disease, including metabolic, vascular, and central nervous system disease. Considerable attention has been focused on ginsenoside $\mathrm{Rb} 1$ derived from their common ownership as an anti-diabetic agent that can attenuate insulin resistance and various complications. Particularly, in vitro and in vivo models have suggested that ginsenoside Rb1 exerts various pharmacological effects on metabolic disorders, including attenuation of glycemia, hypertension, and hyperlipidemia, which depend on the modulation of oxidative stress, inflammatory response, autophagy, and anti-apoptosis effects. Regulation of these pathophysiological mechanisms can improve blood glucose and insulin resistance and protect against macrovascular/microvascular related complications. This review summarizes the pharmacological effects and mechanisms of action of ginsenoside Rb1 in the management of diabetes or diabetic complications. Moreover, a multi-target effect and mechanism analysis of its antidiabetic actions were performed to provide a theoretical basis for further pharmacological studies and new drug development for clinical treatment of type 2 diabetes. In conclusion, ginsenoside Rb1 exerts significant anti-obesity, anti-hyperglycemic, and anti-diabetic effects by regulating the effects of glycolipid metabolism and improving insulin and leptin sensitivities. All of these findings suggest ginsenoside $\mathrm{Rb} 1$ exerts protective effects on diabetes and diabetic complications by the regulation of mitochondrial energy metabolism, improving insulin resistance and alleviating the occurrence complications, which should be further explored. Hence, ginsenoside Rb1 may be developed as a potential anti-obesity, anti-hyperglycemic, and anti-diabetic agent with multi-target effects.
\end{abstract}

Keywords: ginsenoside Rb1; diabetes; diabetic complication; multi-target effects 


\section{Introduction}

Diabetes mellitus (DM) is a metabolic disorder characterized by hyperglycemia caused by insufficient insulin secretion and/or insulin action. The increased prevalence of DM, especially type 2 diabetes (T2DM) [1-3], is a multi-factor disease resulting from both genetic factors, such as obesity, impaired postprandial insulin secretion, and partial pancreatic B-cell damage, and environmental factors, including obesity, unhealthy dietary patterns, lack of exercise, and aging [4]. These factors lead to persistent hyperglycemia and a subsequent decrease in insulin sensitivity, which in turn causes a series of metabolic disorders [5]. Moreover, sustained glucose and lipid metabolism disorder will lead to various microvascular and macrovascular complications, such as stroke, ischemic heart disease, diabetic nephropathy (DN), cognitive dysfunction, and retinopathy [6]. These complications caused by diabetes impose ever-increasing burdens on healthcare systems in developed as well as developing countries. Diabetic macroangiopathy refers to cardiovascular and cerebrovascular diseases, with atherosclerosis as the main manifestation. Diabetic microangiopathy is mainly characterized as the thickening of the basement membrane and the deposition of transparent substances in the retina, kidney, nerve tissue, and elsewhere.

Recently, there has been a shift in the drugs prescribed for T2DM from agents that stimulate insulin secretion, such as sulfonylureas, towards agents that increase insulin sensitivity, such as biguanides (BGs) [7] and thiazolidinediones (SUs) [8-10]. These latter classes of drugs activate the hepatic adenosine monophosphate-activated protein kinase (AMPK) [11-13], phosphatidylinositol 3-kinase (PI3K), and protein kinase B (PKB/Akt) [14-16], stimulate fatty acid oxidation in an AMPK- and peroxisome proliferator activated receptor- $\alpha$ (PPAR- $\alpha$ )-dependent manner, and inhibit the interference with c-Jun amino-terminal kinases (JNKs) and insulin action activated by inflammatory cytokines and free fatty acids [17,18], all of which are new targets and new ways of reducing blood sugar, obesity, and diabetes symptoms.

Glucose transporter type 4 (GLUT4) also plays an important role in maintaining blood glucose homeostasis and its presence can reduce insulin resistance. The primary function of GLUT4 is partial glucose transport, which is mediated by the PI3K and Akt signaling pathways. In addition, many mechanisms initiate and sustain damage to the vasculature, including the classical polyol pathway, glycosylation end products pathway, protein kinase C pathway, and hexosamine pathway $[19,20]$.

Conventional diabetes treatments include SUs, BGs, TZDs [21], and alpha-glucosidase inhibitors [22,23]. These drugs usually have considerable side effects, such as hypoglycemia, drug resistance, dropsy, and weight gain. With advancing research on diabetes, treatment has progressed from only increasing insulin's hypoglycemic effect to controlling glucose metabolism, enhancing insulin receptor sensitivity, inhibiting insulin resistance, regulating protein non-enzymatic glycosylation, and reducing fatty acid metabolism and other aspects [24,25]. Although numerous preventive and therapeutic strategies and drugs for diabetes have been developed, the treatment and management of diabetes remain highly unsatisfactory. Therapies currently used to control and treat diabetes and its complications rely primarily on chemical or biodegradable drugs. What is more serious is that there is also a growing phenomenon of diabetic complications [26]. Therefore, there is an urgent need to develop new, better, and safe natural hypoglycemic agents as alternatives for managing diabetes and its complications.

Traditional Chinese medicines and their natural active ingredients have a variety of hypoglycemic effects and effectively control and delay the development of diabetes and complications by scavenging oxygen free radicals, improving blood hypercoagulability, inhibiting protein non-enzymatic glycation, inhibiting aldose reductase, correcting fat and protein metabolism disorders, and inhibiting platelet aggregation [27-31]. Panax notoginseng (Burk.) F.H.Chen [32] and Panax ginseng C.A.Mey [33] (Araliaceae) are commonly used in Chinese medicine and the roots have been used for the treatment of hemoptysis, hemostasis, and hematoma for several hundred years in China and other Asian countries due to their cardiovascular effects [33-35], including in diabetes and its complications [36-38]. Pharmacological studies have shown that $P$. notoginseng and its extracts have many functions, such as anti-inflammation [39-42], anti-oxidation, platelet aggregation inhibition, blood glucose regulation [43,44] and blood pressure regulation [45-47], insulin resistance improvement [31,48], 
neuronal apoptosis inhibition [49-51], and neuronal protection [52-55]. In particular, the promising role of ginsenoside $\mathrm{Rb} 1$, the main protopanaxadiol-type ginsenoside isolated from $P$. notoginseng and $P$. ginseng, as an anti-diabetic is widely publicized [56-64]. Ginsenoside Rb1 possesses anti-diabetic and insulin-sensitizing properties [56,59].

However, to date, no systematic review has been conducted to assess the protective effects and underlying mechanisms of how ginsenoside $\mathrm{Rb} 1$ combats diabetes and its complications. If a systematic review and analysis of preclinical studies of ginsenoside $\mathrm{Rb} 1$ against diabetes and its complications were to be carried out, all evidence available from animal experiments or preceding clinical trials would provide a theoretical basis for further pharmacological studies and new drug development for clinical treatment of T2MD.

\section{Source and Chemistry}

P. notoginseng and P. ginseng, two of the most widely used traditional Chinese herbs, have an approximately 2500-year medicinal history in Eastern Asia. It is a slow-growing perennial plant that belongs to the genus Panax in the Araliaceae family [65]. The vast array of body systems treated by $P$. notoginseng and $P$. ginseng include the immune system, the nervous system, the cardiovascular system, and blood circulation $[33,35]$. Saponins are one of the main kinds of active ingredient of P. notoginseng $[32,66]$ and P. ginseng $[33,35]$. So far, more than 70 kinds of monomeric saponins have been isolated from different parts of $P$. notoginseng (roots, stems, leaves, flower buds, and seeds.) $[32,66]$ and most of these monomeric saponins are separable [33,35]. These consist of the dammarane type of 20 (S)-protopanaxadiol and 20(S)-protopanaxatriol saponins. Among them, ginsenoside Rb1 (Figure 1A) is the main protopanaxadiol saponin and ginsenoside Re, Rg1 and notoginsenoside R1 (Figure 1B) are the main representative protopanaxatriol components. These four components, shown in Figure 1B, are part of the total saponins of $P$. notoginseng. All ginsenosides have the same four-ring hydrophobic structure, but different numbers of sugar moieties. Ginsenoside Rb1 and Rg1 are the most abundant in P. notoginseng and the quality standard is also based on the total amount of ginsenoside $\mathrm{Rb} 1, \mathrm{Rg} 1$ and notoginsenoside R1, which is not less than $5.0 \%$ as the standard for measuring the P. notoginseng quality. Ginsenoside Rb1, the most important active factor [67], is also isolated from other Panax species, including Panax quinquefolius (American ginseng) and Panax ginseng (Asian ginseng). It is thought that the variability of the sugar component may be associated with the specific action of each ginsenoside [68]. More importantly, Rb1 shows certain pharmacological effects in maintaining blood circulation, improving myocardial ischemia, anti-arrhythmia, anti-shock, anti-diabetic, improving intelligence, anti-aging, anti-oxidation, anti-cell proliferation, and anti-tumor [32,33,35].

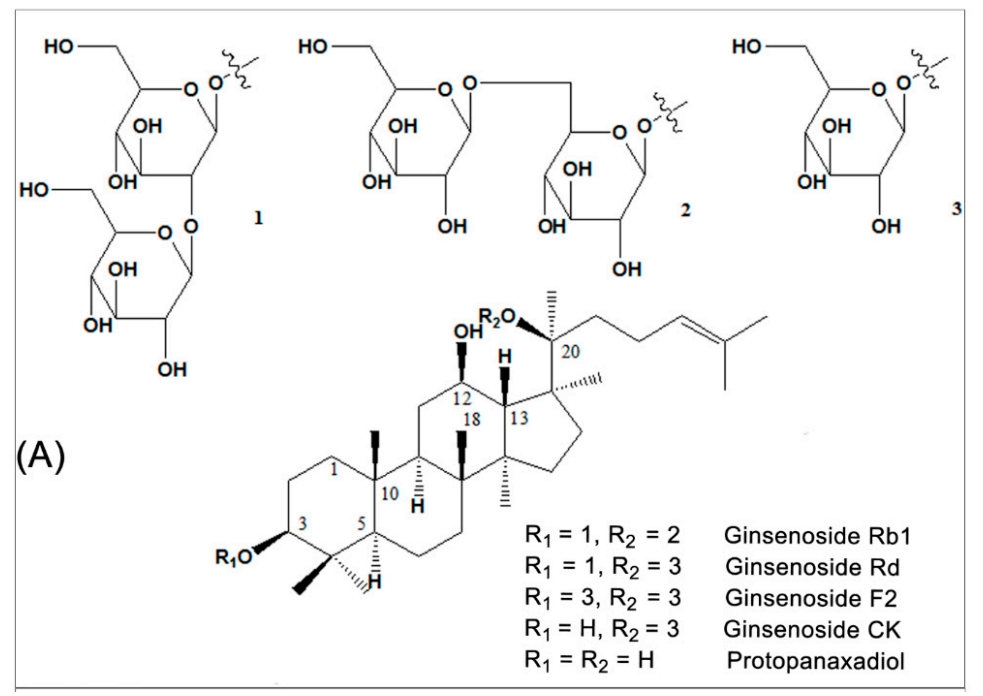

Figure 1. Cont. 


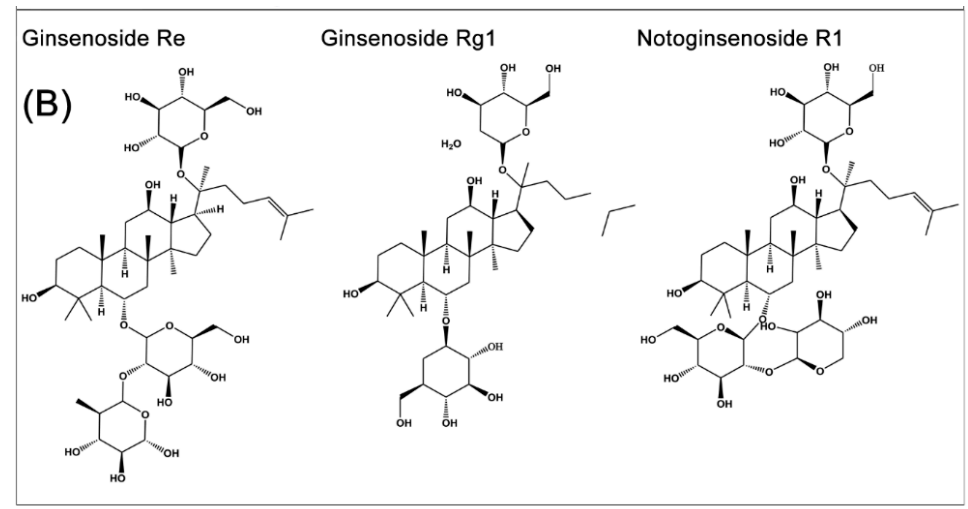

Figure 1. Chemical structural formula of the representative saponin components of Panax notoginseng and Panax ginseng. (A) Component structure of ginsenoside Rb1 and its metabolites; (B) ginsenoside Re, Rg1 and notoginsenoside R1.

\section{Anti-Diabetic Effects and Mechanisms of Ginsenoside Rb1}

Insulin resistance is an abnormal physiological state and the main cause of type 2 diabetes (insulin-independent diabetes), meaning that target cells are not sensitive to insulin and require relatively more insulin to maintain normal blood glucose levels, which can be caused by abnormal structure of insulin, the abnormal binding of insulin receptors, insulin degradation, insulin receptor defects, metabolic signal transmission error, etc. Recently, the tendency of drug prescription for type 2 diabetics has moved from agents that stimulate insulin secretion toward agents that increase insulin sensitivity by activating the hepatic AMPK, PI3K, and Akt activity [12,14-16,69,70].

The increased prevalence of obesity has focused attention on a worldwide problem that is not one of famine or infection, but one of surplus. Increasing research results show ginseng and ginsenoside $\mathrm{Rb} 1$ possess anti-obesity [71], anti-hyperglycemic [72,73], insulin-sensitizing [74], and anti-diabetic properties [75,76], which may be mainly realized by improving glucose tolerance, reducing hepatic fat accumulation $[59,64]$, increasing the sensitivity of insulin, exhibiting adjuvant treatment, suppressing adipocyte lipolysis [77], and regulating adipocyte development and functions [64,73,75]. These effects contribute to the treatment of diabetes and delay in the development and progression of diabetic complications.

\subsection{In Vivo}

Current in vivo results (Table 1) have shown that four-week intraperitoneal administration of ginsenoside $\mathrm{Rb} 1$ could significantly reduce food intake, body weight gain, and body fat content and increase energy expenditure in high-fat diet (HFD)-induced obese mice and rats (adult male Long-Evans rats) $(p<0.01)[62,71]$. Meanwhile, Rb1 may obviously reduce hepatic fat accumulation, suppress adipocyte lipolysis in obese and diabetic mice $(p<0.01)[64,78]$, and decrease fasting blood glucose (FBG) $[78,79]$. All of these contribute to improving glucose tolerance and the sensitivity of insulin, as shown in Table 1.

First, ginsenoside $\mathrm{Rb} 1$, which was injected intraperitoneally ( $60 \mathrm{mg} / \mathrm{kg}$ body mass, daily) for $12 \mathrm{~d}$, decreased body weight growth gain, food consumption, adipose tissue, and leptin levels in KK-Ay DM mice $(p<0.01)$ [73]. Ginsenoside Rb1 ameliorated the HFD-induced increase in FBG, impaired glucose tolerance, and reduced insulin sensitivity to exert its anti-diabetes effects in a HFD-induced mouse model for T2DM $(p<0.01)$ [79].

Second, treatment with ginsenoside $\mathrm{Rb} 1$ ( $20 \mathrm{mg} / \mathrm{kg}$ body mass, daily) for $14 \mathrm{~d}$ alleviated hepatic fat accumulation and increased insulin sensitivity; these effects were accompanied by reduced liver weight and hepatic triglyceride content in obese diabetic $d b / d b$ mice $(p<0.01)$ [64] and upregulated perilipin in 3T3-L1 adipocytes [64]. Treatment with ginsenoside Rb1 by intraperitoneal injection $(20 \mathrm{mg} / \mathrm{kg}$ body mass, daily) for $14 \mathrm{~d}$ also significantly reduced the homeostasis model assessment-insulin resistance 
and elevated glucose consumption of 3T3-L1 adipocytes; FBG and fasting insulin showed a declining trend in male $d b / d b$ mice [78]. The mechanisms may be closely related to activating the insulin signaling pathway (Akt), promoting translocation of GLUTs to increase glucose uptake in adipocytes [78].

Third, intraperitoneal injections of $\mathrm{Rb} 1$ (10 mg/ $\mathrm{kg}$ body mass, daily) for both $21 \mathrm{~d}$ [62] and 4 weeks [71] significantly reduced body weight gain, improved glucose tolerance, homeostasis model assessment, and fasting plasm insulin in HFD-induced obese mice and rats compared to vehicle treatment $(p<0.01)$ [62,71]. Importantly, treatment with ginsenoside $\mathrm{Rb} 1$ also reduced pro-inflammatory cytokines (TNF- $\alpha$, IL-6, and/or IL-1 $\beta$ ) in adipose tissue and the liver, which are involved in regulation of the NF- $\mathrm{BB}$ pathway (p-IKK and p-IкB $\alpha$ ), leptin p-STAT3 signaling, and negative regulators of leptin signaling (SOCS3 and PTP1B) [62]. These effects may improve insulin sensitivity by regulating glucose and lipid metabolism against obesity and diabetes.

Generally, the underlying molecular mechanism is directly bound up with regulating glycolipid metabolism in muscle, liver, and adipose tissues. Ginsenoside $\mathrm{Rb} 1$ may regulate glucose and lipid metabolism, improve glucose tolerance and insulin sensitivity, and reduce inflammatory cytokines and the inflammatory response in adipose tissue and the liver, which is involved in regulation of the NF-KB pathway.

\subsection{In Vitro}

In vitro experimental studies also indicate that ginsenoside $\mathrm{Rb} 1$ possesses insulin-sensitizing activity and regulates the effects of glucose metabolism; thus, this compound may be developed as a potential anti-diabetic drug [61,74-76], as shown in Table 1.

Adipocyte cell lines derived from mice, especially 3T3-L1 cells, are extensively used in adipose tissue metabolism studies [80,81]. It was proved that $\mathrm{Rb} 1$ significantly stimulated basal and insulin-mediated glucose uptake in a time- and dose-dependent manner in 3T3-L1 adipocytes [75], promoted GLUT1 and GLUT4 translocations to the cell surface via increasing the phosphorylation of insulin receptor substrate- 1 and protein kinase B, and stimulated PI3K activity [75]. In addition, $10 \mu \mathrm{M} \mathrm{Rb} 1$ increased lipid accumulation by approximately $56 \%$ [74] and ginsenoside $\mathrm{Rb} 1$ facilitated adipogenesis of 3T3-L1 preadipocytes in a dose-dependent manner. Several processes are involved: Rb1 inhibited the proliferation of preconfluent 3T3-L1 preadipocytes, increased the mRNA and protein expression of the peroxisome proliferator-activated receptor $\gamma(\operatorname{PPAR} \gamma 2)$ and recombinant human CCAAT/enhancer binding protein alpha $(\mathrm{C} / \mathrm{EBP} \alpha)$, as well as the mRNA of ap2, and $\mathrm{Rb} 1$ may be involved in the process of adipose, glucose, and lipid metabolism in differentiating adipocytes $(p<0.05)$ [74].

In C2C12 myotubes, incubation with ginsenoside Rb1 enhanced basal AdipoR1 and AdipoR2 expression in a time- (1-12 h) and dose-dependent (Rb1, 0.001-100 $\mu \mathrm{M})$ manner [61]. In C2C12 myotubes and 3T3-L1 cells, Rb1 induced GLUT4 translocation partly by activating the adiponectin signaling pathway $[61,75]$.

Furthermore, ginsenoside $\mathrm{Rb} 1$ acts as an insulin sensitizer and thus has a hypoglycemic function [82,83]. It activates AMPK [82,83], an important protein associated with energy metabolism, regulates energy metabolism, and promotes glucose uptake by at least partially activating the insulin signaling pathway [82].

In summary, as shown in Figure 2, Rb1 could promote adipogenesis, enhance the GLUT1 and GLUT4 translocation, upregulate the perilipin levels in adipocytes, regulate the glycolipid metabolism, and improve insulin and leptin sensitivities. All of these effects are closely associated with reducing hepatic fat accumulation, suppressing adipocyte lipolysis, decreasing $11 \beta$-hydroxysteroid dehydrogenase type I (11 $\beta$-HSD1) in the liver and adipose tissues, regulating energy metabolism, increasing adiponectin receptor expression, upregulating perilipin in adipocytes [79], improving PPAR $\gamma 2$ and $C / \operatorname{EBP} \alpha$, activating the adiponectin signaling pathway [74], regulating AMPK, PI3K, and Akt signaling pathways [75,82], inhibiting high glucose (HG)-induced caspase-3 and apoptosis [84], negatively regulating the leptin signaling [62,79], and regulating NF- $\mathrm{KB}$ and leptin-STAT3 signaling 
pathways, at least partially, via decrease of inflammatory markers [85]. Hence, ginsenoside Rb1 may be developed as a potential anti-obesity, anti-hyperglycemic, and anti-diabetic agent, as shown in Table 1.

Table 1. Summarized effects and mechanisms of ginsenoside Rb1 on different targets related to diabetes mellitus in animal and in vitro studies.

\begin{tabular}{|c|c|c|c|c|c|c|}
\hline Model & Type & Inducer & Animal/Cell & Effects & Mechanisms & Ref. \\
\hline DM & In vitro & $\begin{array}{l}\text { AdipoR1 sense } \\
\text { siRNA }\end{array}$ & $\begin{array}{l}\mathrm{C} 2 \mathrm{C} 12 \\
\text { myotubes }\end{array}$ & $\begin{array}{l}\uparrow \text { Basal AdipoR levels } \\
\uparrow \text { GLUT4 translocations }\end{array}$ & $\begin{array}{c}\text { } \text { Translocations of } \\
\text { GLUT4; } \\
\text { Adiponectin signaling } \\
\text { pathway }\end{array}$ & [61] \\
\hline $\begin{array}{l}\text { T2DM; } \\
\text { Obesity }\end{array}$ & In vivo & HFD & Obese mouse & $\begin{array}{l}\downarrow \text { Body weight gain } \\
\downarrow \text { Fat accumulation } \\
\uparrow \text { Glucose tolerance }\end{array}$ & $\begin{array}{c}\text { Modulate inflammation } \\
\uparrow \text { Central leptin } \\
\text { sensitivity } \\
\downarrow \text { Pro-inflammatory } \\
\text { cytokines }\end{array}$ & [62] \\
\hline T2DM & In vivo & $d b / d b$ & $\begin{array}{c}\text { C57; } \\
d b / d b \text { mice }\end{array}$ & $\begin{array}{c}\uparrow \text { Insulin sensitivity } \\
\downarrow \text { Adipocyte lipolysis } \\
\downarrow \text { Levels of free fatty } \\
\text { acids } \\
\uparrow \text { Hepatic fat } \\
\text { accumulation } \\
\downarrow \text { Liver weight, hepatic } \\
\text { triglyceride }\end{array}$ & $\begin{array}{c}\downarrow T N F-\alpha \\
\uparrow \text { Perilipin } \\
\uparrow \text { Insulin sensitivity } \\
\uparrow \text { Level of adiponectin }\end{array}$ & [64] \\
\hline $\begin{array}{l}\text { T2DM; } \\
\text { Obesity }\end{array}$ & In vivo & HFD & Rat & $\begin{array}{c}\downarrow \text { Food intake } \\
\downarrow \text { Body weight gain } \\
\downarrow \text { Body fat content } \\
\uparrow \text { Energy expenditure }\end{array}$ & $\begin{array}{c}\uparrow \mathrm{c}-\text { Fos } \\
\downarrow \mathrm{NPY} \\
\downarrow \mathrm{PI} 3 \mathrm{k} / \text { Akt signaling } \\
\text { pathway }\end{array}$ & [71] \\
\hline Obesity & In vivo & KK-Ay & $\begin{array}{c}\text { C57 } \\
\text { KK-Ay mice }\end{array}$ & $\begin{array}{l}\downarrow \text { Body weight gain } \\
\downarrow \text { FBG and food } \\
\text { consumption }\end{array}$ & $\begin{array}{c}\uparrow \text { Insulin/leptin } \\
\text { sensitivities } \\
\downarrow \text { Insulin resistance } \\
\text { index }\end{array}$ & [73] \\
\hline $\begin{array}{l}\text { T2DM; } \\
\text { Obesity }\end{array}$ & In vitro & $\begin{array}{l}\text { Differentiation } \\
\text { inducer }\end{array}$ & 3T3-L1 cells & $\begin{array}{c}\uparrow \text { Glucose uptake } \\
\uparrow \text { Lipid accumulation } \\
\uparrow \text { Proliferation of 3T3-L1 } \\
\text { preadipocytes }\end{array}$ & $\begin{array}{c}\uparrow a p 2, \text { GLUT4 } \\
\uparrow A d i p o g e n e s i s \\
\uparrow \mathrm{PPAR} \gamma 2 \text { and } \mathrm{C} / \mathrm{EBP} \alpha\end{array}$ & [74] \\
\hline $\begin{array}{l}\text { T2DM; } \\
\text { Obesity }\end{array}$ & In vitro & $\begin{array}{l}\text { Differentiation } \\
\text { inducer }\end{array}$ & $\begin{array}{l}\text { 3T3-L1 cells; } \\
\text { C2C12 } \\
\text { myotubes }\end{array}$ & $\begin{array}{l}\uparrow \text { PI3K activity } \\
\uparrow \text { Glucose uptake } \\
\uparrow I R S 1 \text { and PKB } \\
\text { phosphorylation }\end{array}$ & $\begin{array}{l}\text { Activating insulin } \\
\text { signaling pathway }\end{array}$ & [75] \\
\hline $\begin{array}{l}\text { T2DM; } \\
\text { Obesity }\end{array}$ & In vivo & $d b / d b$ & $d b / d b$ mice & $\begin{array}{c}\uparrow \text { GLUT1 and GLUT4 } \\
\uparrow \text { Akt Phosphorylation } \\
\downarrow \text { HOMA-IR and FBG } \\
\text { and FINS }\end{array}$ & $\begin{array}{c}\uparrow \text { Glucose metabolism } \\
\uparrow \text { Insulin sensitizing } \\
\text { activity }\end{array}$ & [78] \\
\hline T2DM & In vivo & HFD & C57BL/C mice & $\begin{array}{c}\uparrow \text { Glucose tolerance } \\
\downarrow 11 \beta \text {-HSD1 levels } \\
\uparrow \text { Fasting blood glucose }\end{array}$ & $\begin{array}{c}\downarrow 11 \beta \text {-HSD1 } \\
\uparrow \text { Insulin sensitivity }\end{array}$ & [79] \\
\hline DM & In vitro & $\begin{array}{c}\text { HG; } \\
\text { Cytokine }\end{array}$ & Rin-m5F & $\begin{array}{c}\downarrow \text { iNOS expression and } \\
\text { NO } \\
\downarrow \text { Pancreatic } \beta \text {-cell } \\
\text { apoptosis }\end{array}$ & $\begin{array}{c}\downarrow \text { Caspase-3 } \\
\downarrow \text { Apoptosis-related } \\
\text { genes }\end{array}$ & [84] \\
\hline T2DM & $\begin{array}{l}\text { In vivo; } \\
\text { In vitro }\end{array}$ & $\begin{array}{l}\text { HFD; } \\
\text { STZ }\end{array}$ & $\begin{array}{l}\text { Male SD rats; } \\
\text { NCI-H716 cells }\end{array}$ & $\begin{array}{l}\uparrow \text { GLP-1 secretion } \\
\uparrow A T P: A D P \text { ratio }\end{array}$ & $\begin{array}{c}\uparrow \text { GLP-1 } \\
\uparrow \text { Proglucagon }\end{array}$ & [86] \\
\hline
\end{tabular}

$\mathrm{C} / \mathrm{EBP} \alpha$, recombinant human CCAAT/enhancer binding protein alpha; DM, diabetes mellitus; DC, diabetic cardiomyopathy; DN, diabetic nephropathy; FBG, fasting blood glucose; FINS, fasting insulin; HOMA-IR, homeostasis model assessment-insulin resistance; HG, high glucose; HFD, high-fat diet; GLUT, glucose transporter; $\mathrm{HOCl}$, hypochlorous acid; GLP-1, glucagon-like peptide-1; IL-6 and/or IL-1 $\beta$, pro-inflammatory cytokines; IRS1, insulin receptor substrate-1; iNOS, inducible nitric oxide synthase; MAPK, mitogen activated protein kinase; MI/R, myocardial ischemia/reperfusion; NO, nitric oxide; PPAR $\gamma$, peroxisome proliferator-activated receptor $\gamma ; \mathrm{PKB} / \mathrm{Akt}$, protein kinase B; PI3K, phosphatidylinositol 3-kinase; Rin-m5F, Rattus pancreatic $\beta$-cell line; RF stands for references; STZ, streptozotocin; SD, Sprague-Dawley rat; T2DM, type 2 diabetes; TNF- $\alpha$, tumor necrosis factor- $\alpha$; $11 \beta-H S D 1$, $11 \beta$-Hydroxysteroid dehydrogenase type I. 
Based on the above summary and analysis, ginsenoside Rb1 exerts significant anti-obesity, anti-hyperglycemic, and anti-diabetic effects by regulating the effects of glycolipid metabolism and improving insulin and leptin sensitivities, as showed in Figure 2. These effects show the characteristics of multiple targets and joint regulation of multiple pathways:

- Inhibit lipolysis and reduce free fats release and ectopic triglycerides deposition;

- Reduce hepatic fat accumulation and suppress adipocyte lipolysis;

- Decrease inflammatory stress in adipose and liver tissues;

- Promote adipogenesis and the 3T3-L1 adipocytes differentiation;

- Upregulate PPAR $\gamma$ and enhance GLUTs expression and translocation of GLUT1/ GLUT4;

- Upregulate perilipin in adipocytes and in fat cells;

- Decrease 11ß-HSD1 and its mRNA in liver and adipose tissue;

- Decrease the expression of inflammatory markers (IL-6, IL-1 $\beta$, and p-IKK);

- Negatively regulate leptin signaling (SOCS3 and PTP1B);

- Inhibit HG-induced caspase-3 activation and apoptosis;

- Increase adiponectin receptor gene expression, upregulate perilipin adipocytes, upregulate $\operatorname{PPAR} \gamma 2, \mathrm{C} / \mathrm{EBP} \alpha$, and activate the adiponectin signaling pathway;

- $\quad$ Regulate PI3K and Akt activity;

- Activate AMPK, regulate energy metabolism, and promote glucose uptake, at least partially, by activating the insulin signaling pathway;

- $\quad$ Regulate NF-кB pathway (p-IKK and p-IкB $\alpha$ ) and leptin-STAT3 signaling.

In summary, ginsenoside $\mathrm{Rb} 1$ acts as an insulin sensitizer and thus has a hypoglycemic function and this compound may be developed as an anti-obesity, anti-hyperglycemic, and anti-diabetic agent (Figure 2).

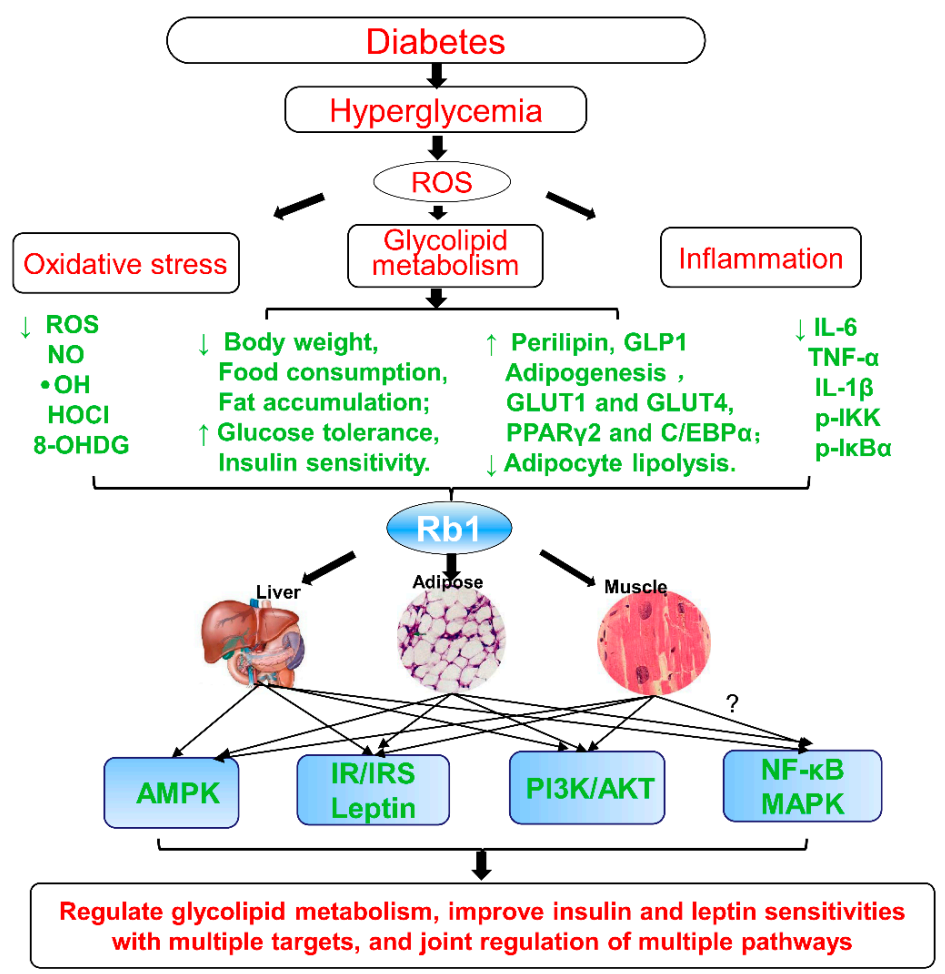

Figure 2. Summary and functional network target analysis of ginsenoside Rb1, which exerts significantly anti-obesity, anti-hyperglycemic, and anti-diabetic effects on diabetes via multiple links across regulatory mechanisms and multi-target effects. $\mathrm{HOCl}$, hypochlorous acid; (IR), insulin signaling pathway; $\cdot \mathrm{OH}$, hydroxyl radical; ROS, reactive oxygen species; $(\downarrow)$, downregulation or inhibition; $(\uparrow)$, upregulation or activation; (?), uncertainty or undetermined. 


\section{Overview of Anti-Diabetic Complications of Ginsenoside Rb1}

Glycolipid metabolism disorder is one of the main physiological characteristics of T2DM, which can result in hyperlipidemia and various microvascular and macrovascular T2DM complications over the long term $[87,88]$. Therefore, timely and effective glycemic control with diet, sulfonylurea, metformin, or insulin, improvements in glycolipid metabolism, and increases in insulin sensitivity play an irreplaceable role in the treatment of diabetes and the prevention and treatment of complications $[88,89]$. Based on the current findings, ginsenoside $\mathrm{Rb} 1$ can lower glucose, increase insulin sensitivity, and regulate lipid metabolism, while also alleviating the occurrence of T2DM-related complications [36,90], including a progressive decline in $\beta$-cell function [84], HG-induced kidney damage or diabetic nephropathy [91], HG-induced nerve damage or diabetic encephalopathy [92,93], and diabetic cardiovascular complications [91,94,95].

\subsection{Protective Effects on the Islets}

Apoptosis is the main form of $\beta$-cell death in diabetes. Ginsenoside $\mathrm{Rb} 1$ has anti-hyperglycemic effects and can protect pancreatic $\beta$-cells by inhibiting apoptosis [84] and hyperglycemia-induced oxidative stress [96]. Ginsenoside $\mathrm{Rb} 1$ treatment significantly reduced the percentages of apoptotic cells, nitric oxide (NO) production, and relative inducible nitric oxide synthase (iNOS) expression levels in a HG/cytokine-induced rat pancreatic $\beta$-cell line (Rin-m5F) and these effects occurred in addition to the downregulation of iNOS, Bax, Fas, and caspase-3 via the caspase-3 pathway [84], as shown in Table 2.

Furthermore, Rb1 promoted glucagon-like peptide-1 (GLP-1) secretion, and increased the intracellular ATP to ADP ratio concentration and the intracellular $\mathrm{Ca}^{2+}$ concentration, as well as significantly increased GLP-1 and upregulated proglucagon; these results indicate that the protective effects on the islets were certainly involved in the enhanced GLP-1 secretion [86], as shown in Table 2. GLP-1 is considered an important incretin that can regulate glucose homeostasis in the gastrointestinal tract after meals. GLP-1 itself has a glucose concentration-dependent hypoglycemic effect and it stimulates islet $\beta$-cells to secrete insulin, inhibit food intake, and improve symptoms of diabetes. Hence, ginsenoside $\mathrm{Rb} 1$ has the protective effects on islet $\beta$-cell via enhancing $\beta$-cell viability and promoting GLP-1 secretion.

It is known that abnormal mitochondrial energy metabolism induces reactive oxygen species (ROS) and NO generation by oxidative stress [97]. Hydroxyl radical and hypochlorous acid, two of the strongest ROS, can be significantly and selectively reduced by Rb1 with unique anti-oxidant mechanisms [96]. Therefore, it can be speculated that $\mathrm{Rb} 1$ can protect islet or pancreatic $\beta$-cells against diabetic injury by inhibiting oxidative stress and apoptosis.

\subsection{Protective Effects on Diabetic Nephropathy}

Glomerular filtration, extracellular matrix hypertrophy, and progressive expansion, which have been considered early features of $\mathrm{DN}$, lead to extra cellular matrix accumulation and glomerular basement membrane thickening, followed by induction of renal fibrosis [98]. Tubulointerstitial fibrosis is a common histological manifestation of chronic kidney disease and the degree of fibrosis is a powerful predictor of glomerular filtration rate decline [98]. Protopanaxadiol and its main representative ingredient, ginsenoside $\mathrm{Rb} 1$, prevented the HG-induced increase in fibronectin expression in mesangial cells cultivated under diabetic conditions and this effect was associated with regulating the p44/42, p38, JNK/SAPK of the mitogen activated protein kinase (MAPK) signal pathways, and Akt phosphorylation levels [60], indicating that $\mathrm{Rb} 1$ may be used as a remedy for $\mathrm{DN}$, a major complication of diabetes mellitus. Also, the effects of $P$. notoginseng saponins (PNS) and $\mathrm{Rb} 1$ were produced partly via reducing the transforming growth factor $\beta 1$ (TGF- $\beta 1$ ) protein expression and blocking the TGF- $\beta 1-S m a d 2 / 3$ signaling pathway [85]. 
Based on the fact that visceral epithelial cell (podocyte) injury plays a key role in the occurrence and development of DN, the early initiation of therapy that aimed at reducing oxidative stress or modulating ROS-sensitive signaling pathways may be used as a remedy for DN and is considered a new target for the treatment of kidney damage. Simultaneously, ginsenoside Rb1 directly decreases the overproduction of ROS [96], protects against mitochondrial dysfunction [99], and restores the imbalance of cellular redox enzymes [100]. Additionally, $\mathrm{Rb} 1$ can reduce excess superoxide anion production and stabilize mitochondrial membrane potential in umbilical vein endothelial cells [101]. Hence, it is speculated that $\mathrm{Rb} 1$ may exert protective effects against HG-induced podocyte injury by inhibiting oxidative stress or modulating ROS-sensitive signaling pathways.

\subsection{Protective Effects on Diabetic Encephalopathy}

Patients with DM have a higher risk of developing Alzheimer's disease (AD) and vascular dementia in the process of aging than non-DM control subjects; this specific disease is recognized as diabetic encephalopathy [102,103]. Metabolic abnormalities, impaired insulin signaling, neuronal apoptosis, oxidative stress, and inflammation are all involved in the development of diabetic encephalopathy (DEP) [48].

As known, ginsenoside $\mathrm{Rb} 1$ shows neuroprotective effects [104,105]. It was proven that treatment with $\mathrm{Rb} 1(1 \mu \mathrm{M})$ protected neurons from HG-induced hippocampal neuron injury, effectively inhibited the protein kinase RNA-like endoplasmic reticulum kinase phosphorylation and glycogen synthase kinase3- $\beta$ expression, and reduced the of $C / E B P$ homologous protein (CHOP) protein levels and mRNA levels $(p<0.01)$ (Table 2), suggesting that ginsenoside Rb1 may protect neurons from HG-induced cell damage by inhibiting glycogen synthase kinase-3 $\beta$ (GSK-3 $\beta$ )-mediated CHOP induction [105]. Moreover, ginsenoside $\mathrm{Rb} 1$ exerted neuroprotective effects against oxidative damage and apoptosis in intermittent HG-mediated Schwann cells [63] and reduced the production of ROS, such as 8-hydroxy-2-deoxy guanosine $(p<0.01)$ [96], inhibited intermittent HG-upregulated Bax, and antagonized intermittent HG-downregulated Bcl-2 [63], which provided a potentially new strategy for preventing and treating diabetic encephalopathy.

\subsection{Protective Effects on Diabetic Cardiovascular Complications}

It has been proven that ginsenoside $\mathrm{Rb} 1$ can not only inhibit food intake, reduce the diabetic patient's weight, regulate blood lipids levels, and improve blood hypercoagulability in diabetic patients, but could also delay the occurrence of diabetic heart disease, including microangiopathy, myocardial lesions, and cardiac autonomic neuropathy [94,95], as well as regulate blood pressure in diabetic patients. The significant preventive and therapeutic effects of $\mathrm{Rb} 1$ on diabetic cardiovascular complications were summarized and shown in Table 2.

Ginsenoside $\mathrm{Rb} 1$ attenuated myocardial ischemia/reperfusion (MI/R) injury in non-diabetic myocardium and in diabetes models [106,107]. Compared to the normal condition, the untreated diabetic condition significantly increased post-ischemic myocardial infarct size, elevated plasma creatine kinase-MB (CK-MB) and lactate dehydrogenase (LDH) release, and reduced blood pressure, accompanied by increased myocardial apoptosis [106]. In contrast, pretreatment of ginsenoside $\mathrm{Rb} 1$ reduced myocardial infarct size, decreased plasma CK and LDH, and increased endothelial nitric oxide synthase (eNOS) expression and NO concentration compared with the MI/R group [85]. It also reduced infarct size, cardiomyocyte apoptosis, and caspase-3 activity compared to the diabetic group [107].

Moreover, the preventive and therapeutic effects of $\mathrm{Rb} 1$ on diabetic cardiovascular complications was determined and verified in the traditional Chinese herbal medicine and multi-component formula, such as the Shensong Yangxin Capsule. Although this is a traditional compound preparation, its constitution of bioactive components has been initially determined, including ginsenoside $\mathrm{Rb} 1$, sodium danshensu, chlorogenic acid, and paeoniflorin. It decreased the heart weight/body weight ratio, attenuated cardiac fibrosis and collagen deposition, and improved the impaired cardiac function of T2DM rats. Meanwhile, it upregulated Smad7, downregulated TGF- $\beta 1$ and p-Smad 
$2 / 3$ protein levels and TGF- $\beta 1$, col-1, col-3, MMP-2, MMP-9, and $\alpha$-SMA RNA levels, inhibited fibrosis, and improved cardiac function by suppressing TGF- $\beta 1 /$ Smad signaling [85].

These effects reveal that ginsenoside $\mathrm{Rb} 1$ may exert double-cardioprotective effects on both $\mathrm{MI} / \mathrm{R}$ injury in diabetes and diabetic damage due to MI/R, partly by inhibiting oxidative stress and apoptosis, enhancing the eNOS expression, and increasing the NO concentration, as well as activating the PI3K/Akt pathway.

Table 2. Summarized effects and mechanisms of ginsenoside $\mathrm{Rb} 1$ on different targets related to diabetic complications in animal and in vitro studies, including $\beta$-cell injury, kidney damage or diabetic nephropathy, nerve damage or diabetic encephalopathy. and diabetic cardiovascular complications.

\begin{tabular}{|c|c|c|c|c|c|c|}
\hline Model & Type & Inducer & Animal/Cell & Effects & Mechanisms & Ref. \\
\hline T2DM & In vivo & $\begin{array}{l}\text { HFD; } \\
\text { HG } \\
\text { STZ }\end{array}$ & $\begin{array}{l}\text { Male Wistar rats; } \\
\text { Intestinal } \\
\text { microflora }\end{array}$ & $\begin{array}{l}\downarrow \downarrow \text { Blood sugar levels } \\
\uparrow \text { Biotransformation pathway } \\
\uparrow \text { Fecal-d-glucosidase activity }\end{array}$ & $\begin{array}{c}\uparrow \text { Pathway } \\
(\mathrm{Rb} 1 \rightarrow \mathrm{Rd} \rightarrow \mathrm{F} 2 \rightarrow \mathrm{CK}) ; \text { gut } \\
\text { microbiota-mediated } \\
\text { bioconversion }\end{array}$ & [57] \\
\hline DM DN & In vitro & HG & Mesangial cells & $\begin{array}{l}\downarrow \text { Phosphorylation of p38, } \\
\text { JNK, and p44/42 MAPK } \\
\downarrow \text { Fibronectin expression }\end{array}$ & $\begin{array}{c}\downarrow \text { Phosphorylation of } \\
\text { p44/42 MAPK, p38 MAPK, } \\
\text { JNK/SAPK, and Akt }\end{array}$ & {$[60]$} \\
\hline DPN & In vitro & HG; & Schwann cells & $\begin{array}{c}\downarrow \text { Bax } \\
\downarrow \text { ROS and 8-OHDG }\end{array}$ & $\begin{array}{c}\uparrow \text { Bcl-2 } \\
\downarrow \text { Apoptosis } \\
\downarrow \text { Oxidative stress }\end{array}$ & {$[63]$} \\
\hline T2DM & In vitro & Inducers & $\begin{array}{l}\text { 3T3-L1 adipocytes } \\
\text { C2C12 myotubes }\end{array}$ & $\begin{array}{c}\uparrow \mathrm{PI} 3 \mathrm{~K} \text { activity } \\
\uparrow \mathrm{Glucose} \text { uptake } \\
\uparrow \mathrm{IRS} 1 \text { and } \mathrm{PKB}\end{array}$ & $\begin{array}{c}\uparrow \text { GLUT1 and GLUT4 } \\
\uparrow \text { Insulin signaling pathway }\end{array}$ & [75] \\
\hline $\begin{array}{l}\text { DC } \\
\text { DM }\end{array}$ & In vivo & STZ & Diabetic rats & $\begin{array}{c}\downarrow \text { Heart weight / body weight } \\
\uparrow \text { Impaired cardiac function } \\
\downarrow \text { Col-1, col-3, MMP-2, MMP-9 } \\
\text { and } \alpha \text {-SMA }\end{array}$ & $\begin{array}{c}\uparrow \text { Smad7 } \\
\downarrow \text { Cardiac fibrosis } \\
\downarrow \text { TGF- } \beta 1 \text { and p-Smad2/3, } \\
\text { TGF- } \beta 1 / \text { Smad signaling }\end{array}$ & [85] \\
\hline DM & In vitro & $\begin{array}{c}\text { HG; } \\
\text { cytokine }\end{array}$ & Rin-m5F & $\begin{array}{c}\downarrow \text { NO production } \\
\downarrow \text { Pancreatic } \beta \text {-cell apoptosis }\end{array}$ & $\begin{array}{c}\downarrow \downarrow \text { iNOS } \\
\downarrow \text { Fas and caspase-3 }\end{array}$ & {$[84]$} \\
\hline T2DM & $\begin{array}{l}\text { In vivo; } \\
\text { In vitro }\end{array}$ & $\begin{array}{l}\text { HFD; } \\
\text { STZ }\end{array}$ & $\begin{array}{l}\text { Male SD rats } \\
\text { NCI-H716 cells }\end{array}$ & $\begin{array}{c}\uparrow \text { Ratio of the ATP:ADP } \\
\uparrow \text { GLP- } 1 \text { secretion }\end{array}$ & $\begin{array}{c}\uparrow \text { GLP-1 } \\
\uparrow \text { Proglucagon }\end{array}$ & [86] \\
\hline DM & In vitro & ROS & Cell-free system & $\downarrow \cdot \mathrm{OH}$ and $\mathrm{HOCl}$ & $\begin{array}{l}\text { Unique anti-oxidant } \\
\text { mechanisms }\end{array}$ & [96]. \\
\hline DM & In vitro & HG & $\begin{array}{l}\text { Hippocampal } \\
\text { neurons }\end{array}$ & $\begin{array}{l}\downarrow \text { Neuronal loss } \\
\uparrow \text { Cell viability }\end{array}$ & $\begin{array}{c}\downarrow \text { CHOP protein } \\
\downarrow \text { p-PERK and p-GSK-3 } \beta\end{array}$ & [105] \\
\hline $\begin{array}{c}\mathrm{DM} \\
\mathrm{MI} / \mathrm{R}\end{array}$ & In vivo & $\begin{array}{l}\mathrm{STZ} \\
\mathrm{MI} / \mathrm{R}\end{array}$ & Male SD rat & $\begin{array}{c}\downarrow \text { Plasma CK and LDH } \\
\downarrow \text { Myocardial infarct size } \\
\downarrow \text { Myocardial oxidative stress }\end{array}$ & $\begin{array}{l}\uparrow \text { eNOS and NO; } \\
\downarrow \text { Oxidative stress }\end{array}$ & [106] \\
\hline $\begin{array}{c}\text { DM } \\
\text { MI/R }\end{array}$ & In vivo & $\begin{array}{l}\mathrm{STZ} \\
\mathrm{MI} / \mathrm{R}\end{array}$ & Male SD rat & $\begin{array}{c}\downarrow \text { Infarct size } \\
\downarrow \text { Caspase- } 3 \text { activity } \\
\downarrow \text { Cardiomyocyte apoptosis }\end{array}$ & $\begin{array}{c}\uparrow \text { Phosphorylated Akt; } \\
\text { activation of PI3K/Akt } \\
\text { pathway }\end{array}$ & [107] \\
\hline T2DM & $\begin{array}{l}\text { In vivo; } \\
\text { In vitro }\end{array}$ & $\begin{array}{l}\text { HFD; } \\
\text { STZ }\end{array}$ & $\begin{array}{l}\text { Male SD rat } \\
\text { Caco- } 2 \text { cells }\end{array}$ & $\begin{array}{c}\uparrow \mathrm{Rb} 1 \text { absorption } \\
\uparrow \mathrm{Rb} 1 \text { systemic exposures } \\
\uparrow \text { Portal } \mathrm{Rb} 1 \text { concentration }\end{array}$ & $\begin{array}{c}\downarrow R \mathrm{R} 1 \text { deglycosylation } \\
\uparrow \mathrm{Rb} 1 \text { intestinal absorption }\end{array}$ & [108] \\
\hline
\end{tabular}

CK, Creatine Kinase; DPN, diabetic peripheral neuropathy; DM, diabetes mellitus; DN, diabetic nephropathy; eNOS, endothelial nitric oxide synthase; GSK-3 $\beta$, glycogen synthase kinase-3 $\beta$; GLUT, glucose transporter; GLP-1, glucagon-like peptide-1; HG, high glucose; HFD, high-fat diet; $\mathrm{HOCl}$, hypochlorous acid; IRS1, insulin receptor substrate-1; LDH, lactate dehydrogenase; MI/R, myocardial ischemia/reperfusion; MAPK, mitogen activated protein kinase; NO, nitric oxide; PERK, protein kinase RNA-like ER kinase; PKB/Akt, protein kinase B; PI3K, phosphatidylinositol 3-kinase; $\mathrm{OH}$, hydroxyl radical; Rin-m5F, Rattus pancreatic $\beta$-cell line; STZ, streptozotocin; SD, Sprague-Dawley rat; RF stands for references; TGF- $\beta 1$, transforming growth factor $\beta 1$; T2DM, type 2 diabetes; 8-OHDG, 8-hydroxy-2-deoxy deoxyguanosine.

\subsection{Intestine and Gut Microbiota Effects}

In addition to the above effects, PNS and ginsenoside Rb1 can modulate the gut microbiota. Ginsenoside $\mathrm{Rb} 1$ has significant hypoglycemic activity in the context of diabetes because its gut permeability is increased and its deglycosylation by intestinal microflora is inhibited [57,108]. On the one hand, $\mathrm{Rb} 1$ passage through a Caco- 2 monolayer was promoted by culturing with diabetic serum and $\mathrm{Rb} 1$ oral exposure significantly increased under diabetic conditions; these effects may be associated with the combined contribution of increased gut permeability and inhibited the ginsenoside $\mathrm{Rb} 1$ 
deglycosylation by the intestinal microflora [108]. On the other hand, ginseng polysaccharides and $\mathrm{Rb} 1$ reinstated the perturbed holistic gut microbiota and promoted fecal-D-glucosidase activity by modulating the gut microbiota and upregulating the transformation pathway of $\mathrm{Rb} 1$ in diabetic rat intestinal microflora ( $\mathrm{Rb} 1 \rightarrow \mathrm{Rd} \rightarrow \mathrm{F} 2 \rightarrow \mathrm{CK}$ ) [76].

In addition, ginsenoside $\mathrm{Rb} 1$ promoted the secretion of GLP-1, a brain gut peptide secreted by ileal endocrine cells. GLP-1 itself has a glucose concentration-dependent hypoglycemic effect and it stimulates islet $\beta$-cells to secrete insulin [109].

Therefore, ginsenoside $\mathrm{Rb} 1$ could improve oral bioavailability, modulate gut microbiota composition/balance, increase gut permeability, and stimulate GLP-1 secretion to exert potential hypoglycemic and anti-diabetic effects.

In addition, ginsenoside $\mathrm{Rb} 1$ not only lowers glucose, increases insulin sensitivity, and regulates lipid metabolism (Figure 2), but also alleviates the occurrence of T2DM-related complications (Figure 3), including the progressive decline in $\beta$-cell function, HG-induced kidney damage or DN, HG-induced nerve damage or diabetic encephalopathy, and diabetic cardiovascular complications, as shown in Figure 3.

\section{Diabetes Complications}

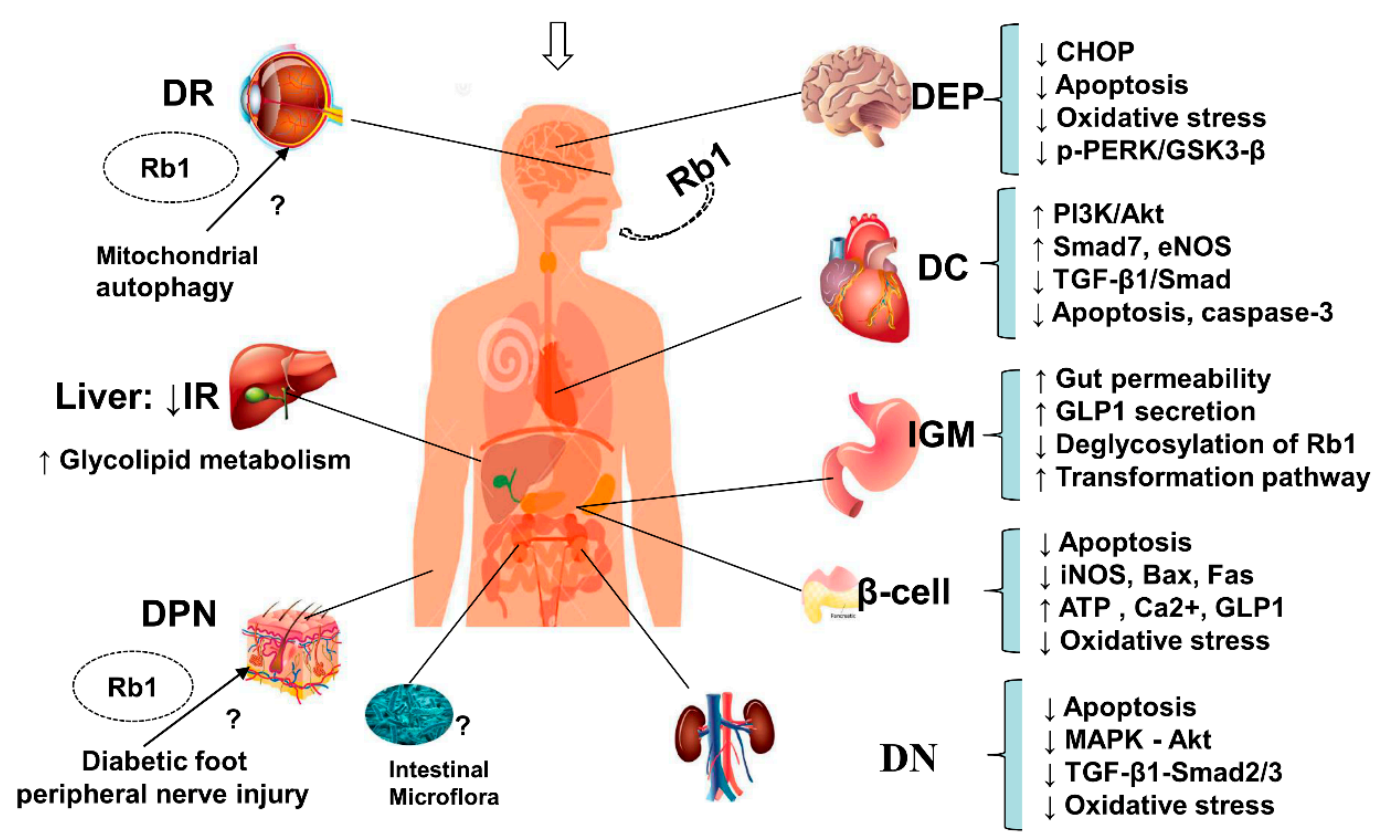

Figure 3. Summary and functional network target analysis of ginsenoside $\mathrm{Rb} 1$, which exerts significant anti-hyperglycemic and anti-diabetic effects on diabetes complications via multiple links across regulatory mechanisms and multi-target effects. IR, insulin resistance; DN, diabetic nephropathy; DEP, diabetic encephalopathy; DC, diabetic cardiovascular complications; DR, diabetic retinopathy; DPN, diabetic peripheral neuropathy; IGM, intestine and gut/microbiota. $(\downarrow)$, downregulation or inhibition; $(\uparrow)$, upregulation or activation; (?), uncertainty or undetermined.

These effects show the characteristics of multiple targets and joint regulation of multiple pathways as follows:

$\mathrm{Rb} 1$ has anti-hyperglycemic effects and protects pancreatic $\beta$-cells by inhibiting oxidative stress induced by hyperglycemia. It also reduces cell apoptosis and NO and 8-OHDG production, promotes GLP-1 secretion, enhances islet $\beta$-cell viability, increases the ratio of intracellular ATP to ADP concentration, downregulates iNOS expression, and decreases $\mathrm{Bax}, \mathrm{Fa}$, and caspase- 3 expression via the caspase-3 pathway. 
- $\mathrm{Rb} 1$ protects neurons from HG-induced cell damage and exerts neuroprotective effects against oxidative damage and apoptosis by inhibiting GSK-3 $\beta$-mediated CHOP induction and reducing ROS production.

- $\quad \mathrm{Rb} 1$ has protective effects against high glucose podocyte injury, kidney damage, and DN by inhibiting oxidative stress. It also decreases ROS overproduction, protects against mitochondrial dysfunction, restores cellular redox enzymes imbalances, and reduces fibronectin expression under diabetic conditions by regulating p44/4, p38-MAPK, JNK/SAPK, and Akt phosphorylation levels, reducing TGF- $\beta 1$ protein expression, and blocking the TGF- $\beta 1-S m a d 2 / 3$ signaling pathway.

- $\quad \mathrm{Rb} 1$ inhibits fibrosis and improves cardiac function by suppressing TGF- $\beta 1 /$ Smad signaling. It also exerts cardioprotective effects on both myocardial ischemia/reperfusion under diabetic conditions and diabetic damage from myocardial ischemia/reperfusion. Rb1 attenuates myocardial ischemia/reperfusion injury and reduces infarct size, cardiomyocyte apoptosis, and caspase-3 activity, partly by inhibiting oxidative stress and apoptosis, enhancing eNOS expression, and increasing NO concentrations, as well as activating the PI3K/Akt pathway.

\section{Conclusion and Recommendation}

Diabetes mellitus, a chronic metabolic disease, is a serious problem throughout the world. It is a metabolic disorder characterized by hyperglycemia caused by insufficient insulin secretion and/or insulin action. Type 2 diabetes is the insulin-dependent type and patients must be treated with insulin permanently. The main pathogenesis of T2DM involves islet $\beta$-cell dysfunction and peripheral insulin resistance. Insulin resistance is the main characteristic of DM. Currently, the number of DM patients increases each year due to changes in living standards and environment and this number is expected to reach 300 million by 2025 [1-3]. After thousands of years of practice, considerable evidence on the use of traditional Chinese medicines and natural medicines for the prevention and treatment of diabetes has accumulated and Chinese medicines and natural medicines have specific curative effects and few side effects. All of these are valuable resources for reference and exploration for the development of new anti-diabetic drugs. Making full use of modern chemical and biological methods to improve our research efforts, it will provide new drugs and ideas for the prevention and treatment of diabetes and its complications [27-31].

Accumulating evidence has shown that ginseng and its main active constituent ginsenoside $\mathrm{Rb} 1$ posse anti-diabetic and insulin-sensitizing properties, which may be partly achieved via their ability to regulate adipocyte development and functions. Meanwhile, ginsenoside $\mathrm{Rb} 1$ not only has the effects of lowering glucose, increasing insulin sensitivity, and regulating lipid metabolism (Figure 2), but it also alleviates the occurrence of T2DM-related complications (Figure 3), including the progressive $\beta$-cell function decline, HG-induced kidney damage, HG-induced nerve damage or diabetic encephalopathy, and diabetic cardiovascular complications, as shown in Figure 3.

In the present review, we summarized the available reports on the therapeutic effects and the molecular mechanisms of ginsenoside $\mathrm{Rb} 1$ in diabetes and its complications. Ginsenoside $\mathrm{Rb} 1$ exerts significant anti-obesity, anti-hyperglycemic, and anti-diabetic effects by regulating the glycolipid metabolism and improving insulin and leptin sensitivities, as shown in Figure 2. Obviously, ginsenoside $\mathrm{Rb1}$, a promising natural hypoglycemic agent, has a variety of hypoglycemic effects and can effectively control and delay the development of diabetes (Figure 2) and diabetic complications (Figure 3) through scavenging oxygen free radicals, inhibiting protein non-enzymatic glycation, inhibiting aldose reductase, correcting fat and protein metabolism disorders, inhibiting platelet aggregation, increasing insulin sensitivity, and alleviating the occurrence of T2DM-related complications via multiple links across regulatory mechanisms and multi-target effects.

Ginsenoside $\mathrm{Rb} 1$, a natural active ingredient, has various pharmacological activities. The current study revealed that $\mathrm{Rb} 1$ exerted anti-diabetic effects involved in multiple signaling molecules and multiple pathways, presenting the characteristic of multiple effects, multiple targets, and multiple pathways (Figures 2 and 3). Therefore, the effects and mechanisms of Rb1 in the prevention and 
treatment of diabetes is comprehensively outlined to illustrate the therapeutic effects of natural active ingredients on systems and complex diseases via multi-pathways, multi-targets and multi-effects, which will provide a therapeutic reference for the treatment of complex metabolic diseases. At present, it is difficult to obtain significant therapeutic effects by treating complex diseases with a single-target strategy. Instead, it provides new ideas and methods with multi-target treatment for such complex diseases. All of these are new perspectives on ginsenoside $\mathrm{Rb} 1$ regulating energy metabolism and improving insulin resistance to exert protective effects on diabetes and diabetic complications, which should be further explored.

Funding: This work was supported by the Fundamental Research Funds for the Central Universities (3332018152), the Beijing Natural Science Foundation (7184229), the Union Youth Science Fund of Peking Union Medical College (2017350015), the China Postdoctoral Science Foundation funded project (2017M610063), the National Natural Science Foundation of China (No. 81503290), the Major Scientific and Technological Special Project for the Special Research Project for TCM (No. 201507004), and the National Natural Science Foundation of China (NO. 81773938).

Conflicts of Interest: The authors declare they have no conflicts of interest.

\section{References}

1. Muoio, D.M.; Newgard, C.B. Mechanisms of disease: Molecular and metabolic mechanisms of insulin resistance and beta-cell failure in type 2 diabetes. Nat. Rev. Mol. Cell Biol. 2008, 9, 193-205. [CrossRef] [PubMed]

2. Kahn, S.E.; Hull, R.L.; Utzschneider, K.M. Mechanisms linking obesity to insulin resistance and type 2 diabetes. Nature 2006, 444, 840. [CrossRef] [PubMed]

3. Venables, M.C.; Jeukendrup, A.E. Physical inactivity and obesity: Links with insulin resistance and type 2 diabetes mellitus. Diabetes Metab. Res. Rev. 2010, 25, S18-S23. [CrossRef] [PubMed]

4. Romero-Aroca, P.; Mendez-Marin, I.; Baget-Bernaldiz, M.; Fernéndez-Ballart, J.; Santos-Blanco, E. Review of the relationship between renal and retinal microangiopathy in diabetes mellitus patients. Curr. Diabetes Rev. 2010, 6, 88-101. [CrossRef] [PubMed]

5. Ferrannini, E.; Natali, A.; Camastra, S.; Nannipieri, M.; Mari, A.; Adam, K.P.; Milburn, M.V.; Kastenmüller, G.; Adamski, J.; Tuomi, T. Early metabolic markers of the development of dysglycemia and type 2 diabetes and their physiological significance. Diabetes 2013, 62, 1730-1737. [CrossRef] [PubMed]

6. Brownlee, M. Biochemistry and molecular cell biology of diabetic complications. Nature 2001, 414, 813-820. [CrossRef] [PubMed]

7. Setter, S.M.; Iltz, J.L.; Thams, J.; Campbell, R.K. Metformin hydrochloride in the treatment of type 2 diabetes mellitus: A clinical review with a focus on dual therapy. Clin. Ther. 2003, 25, 2991-3026. [CrossRef]

8. Nanjan, M.J.; Mohammed, M.; Prashantha Kumar, B.R.; Chandrasekar, M.J.N. Thiazolidinediones as antidiabetic agents: A critical review. Bioorganic Chem. 2018, 77, 548-567. [CrossRef] [PubMed]

9. Oikonomou, E.; Mourouzis, K.; Fountoulakis, P.; Papamikroulis, G.A.; Siasos, G.; Antonopoulos, A.; Vogiatzi, G.; Tsalamadris, S.; Vavuranakis, M.; Tousoulis, D. Interrelationship between diabetes mellitus and heart failure: The role of peroxisome proliferator-activated receptors in left ventricle performance. Heart Fail. Rev. 2018, 23, 389-408. [CrossRef] [PubMed]

10. Thangavel, N.; Al Bratty, M.; Akhtar Javed, S.; Ahsan, W.; Alhazmi, H.A. Targeting peroxisome proliferator-activated receptors using thiazolidinediones: Strategy for design of novel antidiabetic drugs. Int. J. Med. Chem. 2017, 2017, 1069718. [CrossRef] [PubMed]

11. Glosse, P.; Foller, M. AMP-Activated protein kinase (AMPK)-dependent regulation of renal transport. Int. J. Mol. Sci. 2018, 19, 3481. [CrossRef] [PubMed]

12. Rozanska, D.; Regulska-Ilow, B. The significance of anthocyanins in the prevention and treatment of type 2 diabetes. Adv. Clin. Exp. Med. 2018, 27, 135-142. [CrossRef] [PubMed]

13. Wang, Q.; Liu, S.; Zhai, A.; Zhang, B.; Tian, G. AMPK-mediated regulation of lipid metabolism by phosphorylation. Biol. Pharm. Bull. 2018, 41, 985-993. [CrossRef] [PubMed]

14. Garcia-Galiano, D.; Borges, B.C.; Allen, S.J.; Elias, C.F. PI3K signaling in leptin receptor cells: Role in growth and reproduction. J. Neuroendocrinol. 2019. [CrossRef] [PubMed] 
15. John, C.M.; Mohamed Yusof, N.I.S.; Abdul Aziz, S.H.; Mohd Fauzi, F. Maternal cognitive impairment associated with gestational diabetes mellitus-A review of potential contributing mechanisms. Int. J. Mol. Sci. 2018, 19, 3894. [CrossRef] [PubMed]

16. Mabhida, S.E.; Dludla, P.V.; Johnson, R.; Ndlovu, M.; Louw, J.; Opoku, A.R.; Mosa, R.A. Protective effect of triterpenes against diabetes-induced beta-cell damage: An overview of in vitro and in vivo studies. Pharm. Res 2018, 137, 179-192. [CrossRef] [PubMed]

17. Ferguson, R.D.; Gallagher, E.J.; Scheinman, E.J.; Damouni, R.; LeRoith, D. The Epidemiology and Molecular Mechanisms Linking Obesity, Diabetes, and Cancer. Vitam. Horm. 2013, 93, 51-98. [PubMed]

18. Hirosumi, J.; Tuncman, G.; Chang, L.; Görgün, C.Z.; Uysal, K.T.; Maeda, K.; Karin, M.; Hotamisligil, G.S. A central role for JNK in obesity and insulin resistance. Nature 2002, 420, 333-336. [CrossRef] [PubMed]

19. Sheetz, M.J.; King, G.L. Molecular understanding of hyperglycemia's adverse effects for diabetic complications. JAMA 2002, 288, 2579-2588. [CrossRef] [PubMed]

20. Hunt, J.V.; Wolff, S.P. Oxidative glycation and free radical production: A causal mechanism of diabetic complications. Free Radic. Res. Commun. 1990, 12, 115-123. [CrossRef]

21. Ishii, H.; Hayashino, Y.; Akai, Y.; Yabuta, M.; Tsujii, S. Dipeptidyl peptidase-4 inhibitors as preferable oral hypoglycemic agents in terms of treatment satisfaction: Results from a multicenter, 12-week, open label, randomized controlled study in Japan (PREFERENCE 4 study). J. Diabetes Investig. 2018, 9, 137-145. [CrossRef] [PubMed]

22. Choi, K.; Kim, Y.B. Molecular mechanism of insulin resistance in obesity and type 2 diabetes. Korean J. Intern. Med. 2010, 25, 119-129. [CrossRef] [PubMed]

23. Zhou, J.; Huang, K.; Lei, X.G. Selenium and diabetes-evidence from animal studies. Free Radic. Biol. Med. 2013, 65, 1548-1556. [CrossRef] [PubMed]

24. Weyer, C.; Funahashi, T.; Tanaka, S.; Hotta, K.; Matsuzawa, Y.; Pratley, R.E.; Tataranni, P.A. Hypoadiponectinemia in obesity and type 2 diabetes: Close association with insulin resistance and hyperinsulinemia. J. Clin. Endocrinol. Metab. 2001, 86, 1930-1935. [CrossRef] [PubMed]

25. Dios, S.T.D.; Frontanilla, K.V.; Nigro, J.; Ballinger, M.L.; Ivey, M.E.; Cawson, E.A.; Little, P.J. Regulation of the atherogenic properties of vascular smooth muscle proteoglycans by oral anti-hyperglycemic agents. J. Diabetes Its Complicat. 2007, 21, 108-117. [CrossRef] [PubMed]

26. Bekele, B.B. The prevalence of macro and microvascular complications of DM among patients in Ethiopia 1990-2017: Systematic review. Diabetes Metab. Syndr. 2019, 13, 672-677. [CrossRef] [PubMed]

27. Feng, Y.; Fang, Y.; Wang, Y.; Hao, Y. Acupoint therapy on diabetes mellitus and its common chronic complications: A review of its mechanisms. Biomed. Res. Int. 2018, 2018, 3128378. [CrossRef] [PubMed]

28. Lao, Y.; Wang, X.; Xu, N.; Zhang, H.; Xu, H. Application of proteomics to determine the mechanism of action of traditional Chinese medicine remedies. J. Ethnopharmacol. 2014, 155, 1-8. [CrossRef] [PubMed]

29. Sharma, B.R.; Gautam, L.N.; Adhikari, D.; Karki, R. A comprehensive review on chemical profiling of nelumbo nucifera: potential for drug development. Phytother. Res. 2017, 31, 3-26. [CrossRef] [PubMed]

30. Sun, G.D.; Li, C.Y.; Cui, W.P.; Guo, Q.Y.; Dong, C.Q.; Zou, H.B.; Liu, S.J.; Dong, W.P.; Miao, L.N. Review of herbal traditional chinese medicine for the treatment of diabetic nephropathy. J. Diabetes Res. 2016, 2016, 5749857. [CrossRef] [PubMed]

31. Zhang, T.T.; Jiang, J.G. Active ingredients of traditional Chinese medicine in the treatment of diabetes and diabetic complications. Expert Opin. Investig. Drugs 2012, 21, 1625-1642. [CrossRef] [PubMed]

32. Zhou, X.; Chen, L.-L.; Xie, R.F.; Lam, W.; Zhang, Z.-J.; Jiang, Z.-L.; Cheng, Y.-C. Chemosynthesis pathway and bioactivities comparison of saponins in radix and flower of Panax notoginseng (Burk.) F.H. Chen. J. Ethnopharmacol. 2017, 201, 56-72. [CrossRef] [PubMed]

33. Kim, J.H. Pharmacological and medical applications of Panax ginseng and ginsenosides: A review for use in cardiovascular diseases. J. Ginseng Res. 2018, 42, 264-269. [CrossRef] [PubMed]

34. Su, P.; Wang, L.; Du, S.J.; Xin, W.F.; Zhang, W.S. Advance in studies of Panax notoginseng saponins on pharmacological mechanism of nervous system disease. China J. Chin. Mater. Med. 2014, 39, 4516-4521. (In Chinese)

35. Mancuso, C.; Santangelo, R. Panax ginseng and Panax quinquefolius: From pharmacology to toxicology. Food Chem. Toxicol. 2017, 107, 362-372. [CrossRef] [PubMed]

36. Behl, T.; Kotwani, A. Chinese herbal drugs for the treatment of diabetic retinopathy. J. Pharm. Pharmacol. 2017, 69, 223-235. [CrossRef] [PubMed] 
37. Chen, Z.H.; Li, J.; Liu, J.; Zhao, Y.; Zhang, P.; Zhang, M.X.; Zhang, L. Saponins isolated from the root of Panax notoginseng showed significant anti-diabetic effects in KK-Ay mice. Am. J. Chin. Med. 2008, 36, 939-951. [CrossRef] [PubMed]

38. Du, Y.G.; Wang, L.P.; Qian, J.W.; Zhang, K.N.; Chai, K.F. Panax notoginseng saponins protect kidney from diabetes by up-regulating silent information regulator 1 and activating antioxidant proteins in rats. Chin. J. Integr. Med. 2016, 22, 910-917. [CrossRef] [PubMed]

39. Allison, D.J.; Ditor, D.S. The common inflammatory etiology of depression and cognitive impairment: A therapeutic target. J. Neuroinflamm. 2014, 11, 151. [CrossRef] [PubMed]

40. Jeon, S.W.; Kim, Y.K. Neuroinflammation and cytokine abnormality in major depression: Cause or consequence in that illness? World J. Psychiatry 2016, 6, 283-293. [CrossRef] [PubMed]

41. Zhang, J.; Ding, L.; Wang, B.; Ren, G.; Sun, A.; Deng, C.; Wei, X.; Mani, S.; Wang, Z.; Dou, W. Notoginsenoside $\mathrm{R} 1$ attenuates experimental inflammatory bowel disease via pregnane $\mathrm{X}$ receptor activation. J. Pharmacol. Exp. Ther. 2015, 352, 315-324. [CrossRef] [PubMed]

42. Zheng, X.; Liang, Y.; Kang, A.; Ma, S.J.; Xing, L.; Zhou, Y.Y.; Dai, C.; Xie, H.; Xie, L.; Wang, G.J.; et al. Peripheral immunomodulation with ginsenoside Rg1 ameliorates neuroinflammation-induced behavioral deficits in rats. Neuroscience 2014, 256, 210-222. [CrossRef] [PubMed]

43. Xie, T.; Zhou, X.P.; Lin, L.L.; Xu, J.Y.; Shen, C.S.; Feng, Z.; Zhou, L.L.; Shan, J.J. Metabolomics analysis of Tripterygium wilfordii formulation based on theory of detoxicity compatibility. China J. Chin. Mater. Med. 2016, 41, 1124-1129. (In Chinese) [CrossRef]

44. Zhang, H.; Li, Z.; Zhou, Z.; Yang, H.; Zhong, Z.; Lou, C. Antidepressant-like effects of ginsenosides: A comparison of ginsenoside Rb3 and its four deglycosylated derivatives, $\mathrm{Rg} 3, \mathrm{Rh} 2$, compound $\mathrm{K}$, and 20(S)-protopanaxadiol in mice models of despair. Pharmacol. Biochem. Behav. 2016, 140, 17-26. [CrossRef] [PubMed]

45. Pang, H.H.; Li, M.Y.; Wang, Y.; Tang, M.K.; Ma, C.H.; Huang, J.M. Effect of compatible herbs on the pharmacokinetics of effective components of Panax notoginseng in Fufang Xueshuantong Capsule. J. Zhejiang Univ. Sci. B 2017, 18, 343-352. [CrossRef] [PubMed]

46. Tian, Z.; Pang, H.; Du, S.; Lu, Y.; Zhang, L.; Wu, H.; Guo, S.; Wang, M.; Zhang, Q. Effect of Panax notoginseng saponins on the pharmacokinetics of aspirin in rats. J. Chromatogr. B 2017, 1040, 136-143. [CrossRef] [PubMed]

47. Zhao, S.; Zheng, M.X.; Chen, H.E.; Wu, C.Y.; Wang, W.T. Effect of panax notoginseng saponins injection on the p38MAPK pathway in lung tissue in a rat model of hypoxic pulmonary hypertension. Chin. J. Integr. Med. 2015, 21, 147-151. [CrossRef] [PubMed]

48. Zhai, Y.; Meng, X.; Luo, Y.; Wu, Y.; Ye, T.; Zhou, P.; Ding, S.; Wang, M.; Lu, S.; Zhu, L. Notoginsenoside R1 ameliorates diabetic encephalopathy by activating the Nrf2 pathway and inhibiting NLRP3 inflammasome activation. Oncotarget 2018, 9, 9344-9363. [CrossRef] [PubMed]

49. Hou, Q.L.; Wang, Y.; Li, Y.B.; Hu, X.L.; Wang, S.L. Protective effect of notoginsenoside R1 on neuron injury induced by OGD/R through ATF6/Akt signaling pathway. China J. Chin. Mater. Med. 2017, 42, 1167-1174. (In Chinese)

50. Li, W.; Ling, S.; Yang, Y.; Hu, Z.; Davies, H.; Fang, M. Systematic hypothesis for post-stroke depression caused inflammation and neurotransmission and resultant on possible treatments. Neuro Endocrinol. Lett. 2014, 35, 104-109. [PubMed]

51. Yang, X.; Yang, S.; Hong, C.; Yu, W.; Guonian, W. Panax Notoginseng Saponins attenuates sevofluraneinduced nerve cell injury by modulating AKT signaling pathway. Mol. Med. Rep. 2017, 16, 7829-7834. [CrossRef] [PubMed]

52. Wang, T.; Guo, R.; Zhou, G.; Zhou, X.; Kou, Z.; Sui, F.; Li, C.; Tang, L.; Wang, Z. Traditional uses, botany, phytochemistry, pharmacology and toxicology of Panax notoginseng (Burk.) F.H. Chen: A review. J. Ethnopharmacol. 2016, 188, 234-258. [CrossRef] [PubMed]

53. Berge, L.I.; Riise, T. Comorbidity between Type 2 diabetes and depression in the adult population: Directions of the association and its possible pathophysiological mechanisms. Int. J. Endocrinol. 2015, 2015, 164760. [CrossRef] [PubMed]

54. Xie, W.; Meng, X.; Zhai, Y.; Zhou, P.; Ye, T.; Wang, Z.; Sun, G.; Sun, X. Panax notoginseng saponins: A review of its mechanisms of antidepressant or anxiolytic effects and network analysis on phytochemistry and pharmacology. Molecules 2018, 23, 940. [CrossRef] [PubMed] 
55. Xie, W.; Zhou, P.; Sun, Y.; Meng, X.; Dai, Z.; Sun, G.; Sun, X. Protective effects and target network analysis of ginsenoside Rg1 in cerebral ischemia and reperfusion injury: A comprehensive overview of experimental studies. Cells 2018, 7, 270. [CrossRef] [PubMed]

56. Chen, C.F.; Chiou, W.F.; Zhang, J.T. Comparison of the pharmacological effects of Panax ginseng and Panax quinquefolium. Acta Pharmacol. Sin. 2008, 29, 1103-1108. [CrossRef] [PubMed]

57. Chen, F.; Wen, Q.; Jiang, J.; Li, H.L.; Tan, Y.F.; Li, Y.H.; Zeng, N.K. Could the gut microbiota reconcile the oral bioavailability conundrum of traditional herbs? J. Ethnopharmacol. 2016, 179, 253-264. [CrossRef] [PubMed]

58. Li, S.; Tang, Y.; Liu, C.; Zhang, Y. Development of a method to screen and isolate potential alpha-glucosidase inhibitors from Panax japonicus CA Meyer by ultrafiltration, liquid chromatography, and counter-current chromatography. J. Sep. Sci. 2015, 38, 2014-2023. [CrossRef] [PubMed]

59. Li, X.; Wu, L.; Fan, X.; Zhang, B.; Gao, X.; Wang, Y.; Cheng, Y. Network pharmacology study on major active compounds of Fufang Danshen formula. China J. Chin. Mater. Med. 2011, 36, 2911-2915. (In Chinese)

60. Park, M.J.; Bae, C.S.; Lim, S.K.; Kim, D.I.; Lim, J.C.; Kim, J.C.; Han, H.J.; Moon, J.H.; Kim, K.Y.; Yoon, K.C.; et al. Effect of protopanaxadiol derivatives in high glucose-induced fibronectin expression in primary cultured rat mesangial cells: Role of mitogen-activated protein kinases and Akt. Arch. Pharmacal. Res. 2010, 33, 151-157. [CrossRef] [PubMed]

61. Tabandeh, M.R.; Jafari, H.; Hosseini, S.A.; Hashemitabar, M. Ginsenoside Rb1 stimulates adiponectin signaling in C2C12 muscle cells through up-regulation of AdipoR1 and AdipoR2 proteins. Pharm. Biol. 2015, 53, 125-132. [CrossRef] [PubMed]

62. Wu, Y.; Yu, Y.; Szabo, A.; Han, M.; Huang, X.F. Central inflammation and leptin resistance are attenuated by ginsenoside Rb1 treatment in obese mice fed a high-fat diet. PLoS ONE 2014, 9, e92618. [CrossRef] [PubMed]

63. Xue, B.; Sun, L.; Li, X.; Wang, X.; Zhang, Y.; Mu, Y.; Liang, L. Ginsenoside Rb1 relieves glucose fluctuation-induced oxidative stress and apoptosis in Schwann cells. Neural Regen. Res. 2012, 7, $2340-2346$. [CrossRef] [PubMed]

64. Yu, X.; Ye, L.; Zhang, H.; Zhao, J.; Wang, G.; Guo, C.; Shang, W. Ginsenoside Rb1 ameliorates liver fat accumulation by upregulating perilipin expression in adipose tissue of $\mathrm{db} / \mathrm{db}$ obese mice. J. Ginseng Res. 2015, 39, 199-205. [CrossRef] [PubMed]

65. Sanada, S.; Kondo, N.; Shoji, J.; Tanaka, O.; Shibata, S. Studies on the saponins of ginseng. II. Structures of ginsenoside-Re, -Rf and-Rg2. Chem. Pharm. Bull. 2008, 22, 2407-2412. [CrossRef]

66. Chen, Q.S. Pharmacological studies on notoginseng saponins isolated from the fibrous root of Panax notoginseng. Zhong Yao Tong Bao 1987, 12, 45-47. [PubMed]

67. Washida, D.; Kitanaka, S. Determination of polyacetylenes and ginsenosides in Panax species using high performance liquid chromatography. Chem. Pharm. Bull. 2003, 51, 1314-1317. [CrossRef] [PubMed]

68. Nah, S.Y.; Park, H.J.; Mccleskey, E.W. A trace component of ginseng that inhibits Ca2+ channels through a pertussis toxin-sensitive G protein. Proc. Natl. Acad. Sci. USA 1995, 92, 8739-8743. [CrossRef] [PubMed]

69. Wang, B.; Cheng, K.K. Hypothalamic AMPK as a Mediator of Hormonal Regulation of Energy Balance. Int. J. Mol. Sci. 2018, 19, 3552. [CrossRef] [PubMed]

70. Lyons, C.L.; Roche, H.M. Nutritional Modulation of AMPK-Impact upon Metabolic-Inflammation. Int. J. Mol. Sci. 2018, 19, 3092. [CrossRef] [PubMed]

71. Xiong, Y.; Shen, L.; Liu, K.J.; Tso, P.; Xiong, Y.; Wang, G.; Woods, S.C.; Liu, M. Antiobesity and antihyperglycemic effects of ginsenoside Rb1 in rats. Diabetes 2010, 59, 2505-2512. [CrossRef] [PubMed]

72. Waki, I.; Kyo, H.; Yasuda, M.; Kimura, M. Effects of a hypoglycemic component of ginseng radix on insulin biosynthesis in normal and diabetic animals. J. Pharm. Dyn. 1982, 5, 547-554. [CrossRef]

73. Zhong, Z.D.; Wang, C.M.; Wang, W.; Shen, L.; Chen, Z.H. Major hypoglycemic ingredients of Panax notoginseng saponins for treating diabetes. J. Sichuan Univ. 2014, 45, 235-239. (In Chinese)

74. Shang, W.; Yang, Y.; Jiang, B.; Jin, H.; Zhou, L.; Liu, S.; Chen, M. Ginsenoside Rb1 promotes adipogenesis in 3T3-L1 cells by enhancing PPARgamma2 and C/EBPalpha gene expression. Life Sci. 2007, 80, 618-625. [CrossRef] [PubMed]

75. Shang, W.; Yang, Y.; Zhou, L.; Jiang, B.; Jin, H.; Chen, M. Ginsenoside Rb1 stimulates glucose uptake through insulin-like signaling pathway in 3T3-L1 adipocytes. J. Endocrinol. 2008, 198, 561-569. [CrossRef] [PubMed]

76. Li, J.; Li, R.; Li, N.; Zheng, F.; Dai, Y.; Ge, Y.; Yue, H.; Yu, S. Mechanism of antidiabetic and synergistic effects of ginseng polysaccharide and ginsenoside Rb1 on diabetic rat model. J. Pharm. Biomed. Anal. 2018, 158, 451-460. [CrossRef] [PubMed] 
77. Xie, Z.; Loi Truong, T.; Zhang, P.; Xu, F.; Xu, X.; Li, P. Dan-Qi prescription ameliorates insulin resistance through overall corrective regulation of glucose and fat metabolism. J. Ethnopharmacol. 2015, 172, 70-79. [CrossRef] [PubMed]

78. Shang, W.B.; Guo, C.; Zhao, J.; Yu, X.Z.; Zhang, H. Ginsenoside Rb1 upregulates expressions of GLUTs to promote glucose consumption in adiopcytes. China J. Chin. Mater. Med. 2014, 39, 4448-4452.

79. Song, B.; Ding, L.; Zhang, H.; Chu, Y.; Chang, Z.; Yu, Y.; Guo, D.; Zhang, S.; Liu, X. Ginsenoside Rb1 increases insulin sensitivity through suppressing 11beta-hydroxysteroid dehydrogenase type I. Am. J. Transl. Res. 2017, 9, 1049-1057. [PubMed]

80. Sadie-Van Gijsen, H. Adipocyte biology: It is time to upgrade to a new model. J. Cell. Physiol. 2018, 234, 2399-2425. [CrossRef] [PubMed]

81. Smith, C.J.; Wejksnora, P.J.; Warner, J.R.; Rubin, C.S.; Rosen, O.M. Insulin-stimulated protein phosphorylation in 3T3-L1 preadipocytes. Proc. Natl. Acad. Sci. USA 1979, 76, 2725-2729. [CrossRef] [PubMed]

82. Shen, L.; Haas, M.; Wang, D.Q.; May, A.; Lo, C.C.; Obici, S.; Tso, P.; Woods, S.C.; Liu, M. Ginsenoside Rb1 increases insulin sensitivity by activating AMP-activated protein kinase in male rats. Physiol. Rep. 2015, 3, e12543. [CrossRef] [PubMed]

83. Shen, L.; Xiong, Y.; Wang, D.Q.; Howles, P.; Basford, J.E.; Wang, J.; Xiong, Y.Q.; Hui, D.Y.; Woods, S.C.; Liu, M. Ginsenoside $\mathrm{Rb} 1$ reduces fatty liver by activating AMP-activated protein kinase in obese rats. J. Lipid Res. 2013, 54, 1430-1438. [CrossRef] [PubMed]

84. Chen, F.; Chen, Y.; Kang, X.; Zhou, Z.; Zhang, Z.; Liu, D. Anti-apoptotic function and mechanism of ginseng saponins in Rattus pancreatic beta-cells. Biol. Pharm. Bull. 2012, 35, 1568-1573. [CrossRef] [PubMed]

85. Shen, N.; Li, X.; Zhou, T.; Bilal, M.U.; Du, N.; Hu, Y.; Qin, W.; Xie, Y.; Wang, H.; Wu, J.; et al. Shensong Yangxin Capsule prevents diabetic myocardial fibrosis by inhibiting TGF-beta1/Smad signaling. J. Ethnopharmacol. 2014, 157, 161-170. [CrossRef] [PubMed]

86. Liu, C.; Zhang, M.; Hu, M.Y.; Guo, H.F.; Li, J.; Yu, Y.L.; Jin, S.; Wang, X.T.; Liu, L.; Liu, X.D. Increased glucagon-like peptide-1 secretion may be involved in antidiabetic effects of ginsenosides. J. Endocrinol. 2013, 217, 185-196. [CrossRef] [PubMed]

87. DeFronzo, R.A. Pharmacologic therapy for type 2 diabetes mellitus. Ann. Intern. Med. 1999, 131, $281-303$. [CrossRef] [PubMed]

88. Turner, R.C.; Cull, C.A.; Frighi, V.; Holman, R.R. Glycemic control with diet, sulfonylurea, metformin, or insulin in patients with type 2 diabetes mellitus: Progressive requirement for multiple therapies (UKPDS 49). UK Prospective Diabetes Study (UKPDS) Group. JAMA 1999, 281, 2005-2012. [CrossRef] [PubMed]

89. Cushman, W.C.; Evans, G.W.; Byington, R.P.; Goff, D.C.; Grimm, R.H.; Cutler, J.A.; Simons-Morton, D.G.; Basile, J.N.; Corson, M.A.; Probstfield, J.L. Effects of intensive blood-pressure control in type 2 diabetes mellitus. N. Engl. J. Med. 2010, 362, 1575-1585. [PubMed]

90. Uzayisenga, R.; Ayeka, P.A.; Wang, Y. Anti-diabetic potential of Panax notoginseng saponins (PNS): A review. Phytother. Res. 2014, 28, 510-516. [CrossRef] [PubMed]

91. Bloomgarden, Z.T. Diabetes Complications. Diabetes Care 2004, 27, 1506. [CrossRef] [PubMed]

92. Jiping, L.; Shuyuan, W.; Liang, F.; Dongying, M.; Qiang, F.; Yu, S.; Xiaobin, J.; Shiping, M. Hypoglycemic and antioxidant activities of paeonol and its beneficial effect on diabetic encephalopathy in streptozotocin-induced diabetic rats. J. Med. Food 2013, 16, 577-586.

93. Sima, A.A.; Zhang, W.; Kreipke, C.W.; Rafols, J.A.; Hoffman, W.H. Inflammation in Diabetic Encephalopathy is Prevented by C-Peptide. Rev. Diabet. Stud. 2009, 6, 37-42. [CrossRef] [PubMed]

94. Ahmad, F.K.; Zhiheng, H.; King, G.L. Molecular targets of diabetic cardiovascular complications. Curr. Drug Targets 2005, 6, 487-494. [CrossRef] [PubMed]

95. Desmond, J.; Hirofumi, H.; Griendling, K.K. Oxidative stress and diabetic cardiovascular complications. Free Radic. Biol. Med. 2006, 40, 183-192.

96. Lu, J.M.; Weakley, S.M.; Yang, Z.; Hu, M.; Yao, Q.; Chen, C. Ginsenoside Rb1 directly scavenges hydroxyl radical and hypochlorous acid. Curr. Pharm. Des. 2012, 18, 6339-6347. [CrossRef] [PubMed]

97. Zhu, J.; Wang, K.Z.; Chu, C.T. After the banquet: Mitochondrial biogenesis, mitophagy, and cell survival. Autophagy 2013, 9, 1663-1676. [CrossRef] [PubMed]

98. Marini, M.G.; Sonnino, C.; Previtero, M.; Biasucci, L.M. Targeting inflammation: impact on atherothrombosis. J. Cardiovasc. Transl. Res. 2014, 7, 9-18. [CrossRef] [PubMed] 
99. Li, J.; Shao, Z.H.; Xie, J.T.; Wang, C.Z.; Ramachandran, S.; Yin, J.J.; Aung, H.; Li, C.Q.; Qin, G.; Vanden Hoek, T.; et al. The effects of ginsenoside Rb1 on JNK in oxidative injury in cardiomyocytes. Arch. Pharmacal Res. 2012, 35, 1259-1267. [CrossRef] [PubMed]

100. Chen, C.; Jiang, J.; Lu, J.M.; Chai, H.; Wang, X.; Lin, P.H.; Yao, Q. Resistin decreases expression of endothelial nitric oxide synthase through oxidative stress in human coronary artery endothelial cells. Am. J. Physiol. Heart Circ. Physiol. 2010, 299, H193-H201. [CrossRef] [PubMed]

101. Hui, C.; Qiuyan, W.; Lifeng, H.; Tian, X.; Yan, F. Ginsenoside Rb1 inhibits tumor necrosis factor-alpha-induced vascular cell adhesion molecule-1 expression in human endothelial cells. Biol. Pharm. Bull. 2008, 31, 2050.

102. Wang, Z.; Huang, Y.; Cheng, Y.; Tan, Y.; Wu, F.; Wu, J.; Shi, H.; Zhang, H.; Yu, X.; Gao, H. Endoplasmic reticulum stress-induced neuronal inflammatory response and apoptosis likely plays a key role in the development of diabetic encephalopathy. Oncotarget 2016, 7, 78455-78472. [CrossRef] [PubMed]

103. Carlos Alberto, Y.W.; Helena Maria, T.B.; Carmen Regla, V. GABAergic modulation in diabetic encephalopathy-related depression. Curr. Pharm. Des. 2015, 21, 4980-4988.

104. Sang, H.L.; Jung, B.H.; Sun, Y.K.; Lee, E.H.; Chung, B.C. The antistress effect of ginseng total saponin and ginsenoside $\mathrm{Rg} 3$ and $\mathrm{Rb} 1$ evaluated by brain polyamine level under immobilization stress. Pharmacol. Res. 2006, 54, 46-49.

105. Liu, D.; Zhang, H.; Gu, W.; Liu, Y.; Zhang, M. Ginsenoside Rb1 protects hippocampal neurons from high glucose-induced neurotoxicity by inhibiting GSK3beta-mediated CHOP induction. Mol. Med. Rep. 2014, 9, 1434-1438. [CrossRef] [PubMed]

106. Xia, R.; Zhao, B.; Wu, Y.; Hou, J.B.; Zhang, L.; Xu, J.J.; Xia, Z.Y. Ginsenoside Rb1 preconditioning enhances eNOS expression and attenuates myocardial ischemia/reperfusion injury in diabetic rats. J. Biomed. Biotechnol. 2011, 2011, 767930. [CrossRef] [PubMed]

107. Wu, Y.; Xia, Z.Y.; Dou, J.; Zhang, L.; Xu, J.J.; Zhao, B.; Lei, S.; Liu, H.M. Protective effect of ginsenoside Rb1 against myocardial ischemia/reperfusion injury in streptozotocin-induced diabetic rats. Mol. Biol. Rep. 2011, 38, 4327-4335. [CrossRef] [PubMed]

108. Liu, C.; Hu, M.; Guo, H.; Zhang, M.; Zhang, J.; Li, F.; Zhong, Z.; Chen, Y.; Li, Y.; Xu, P.; et al. Combined contribution of increased intestinal permeability and inhibited deglycosylation of ginsenoside Rb1 in the intestinal tract to the enhancement of ginsenoside $\mathrm{Rb} 1$ exposure in diabetic rats after oral administration. Drug Metab. Dispos. 2015, 43, 1702-1710. [CrossRef] [PubMed]

109. Holst, J.J. The physiology of glucagon-like peptide 1. Physiol. Rev. 2007, 87, 1409-1439. [CrossRef] [PubMed] 